PROCEEDINGS OF THE UNITED STATES NATIONAL MUSEUM

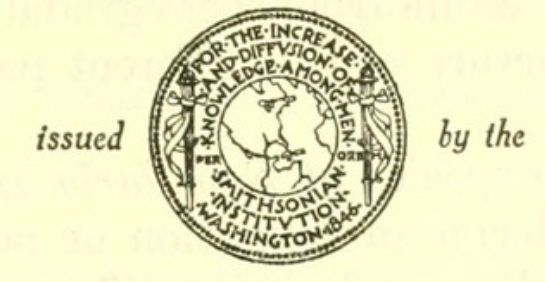

SMITHSONIAN INSTITUTION

U. S. NATIONAL MUSEUM

\title{
A NEW MARINE ANNELID FROM FLORIDA
}

\section{By Olga Hartman}

Sixteen or more species and subspecies of the annelid genus Sabellaria Lamarck (family Sabellariidae Johnston) have been named from widely scattered localities. Three are described from New Zealand (Augener, 1926), 2 come from west Africa (Augener, 1918), 2 are from India or Indo-Pacific areas (Gravier, 1909, and Fauvel, 1930), 2 are European (Fauvel, 1927), and 12 are from various parts of the Western Hemisphere (Hartman, 1944). Most species occur in warmer seas and littoral zones. The recovery of yet another one from Florida is the basis of this report. The specimens were collected by Prof. T. A. Stephenson, of the University College of Wales, for whom the subspecies is named. The type collection is deposited in the United States National Museum. The illustrations were drawn by Anker Petersen.

The most conspicuous characters that distinguish the known species of the genus Sabellaria from one another are structural features of the opercular paleae, usually designated for their position in outer, middle, and inner rows, although the last two rows are presumed to represent a single one in alternating series. These paleae are segmentally formed setal modifications that arise from notopodial parts of the first several (possibly two) visible segments. These parts are conspicuously shifted forward at the time of metamorphosis so as to lie in front of the oral structures (see fig. 40,a). During the life of the individual the paleae are continuously formed as secretions of special cells located at the dorsal end of the setal fascicles, and are replaced, as are other setae. In consequence, younger or smaller in- 
dividuals of a single species may have fewer or smaller paleae than larger representatives. Aside from these gradations, there is remarkable uniformity in structure of the different paleae for a particular species.

In other respects the species of Sabellaria are closely akin. The body consists of an anterior prolongation or peduncle with a distal operculum; the peduncle may have specific patterns of coloration. The ventral mouth with its accessory parts (oral tentacles and paired palpi) is located at the posterior end and ventral side of the peduncle; it is usually not seen unless the several transverse rows of oral tentacles are pushed aside. This is followed by the thorax, abdomen, and cauda. The thorax consists of two anterior thoracic setigerous segments, represented by neuropodia only, and three biramous parathoracic segments, provided with alternating paleae and slender setae in notopodia and limbate setae in neuropodia. The abdomen consists of a variable number of biramous segments with uncinigerous tori above and slender fascicles of setae below. This is followed by a slenderer, usually cylindrical smooth cauda with a terminal anus. Branchiae are simple, tapering, notopodial prolongations, usually somewhat crenulate at the margins and present on most body segments. All setae are simple but some are modified as paleae or uncini.

TABLE 1.-Comparison of Western Hemisphere species and subspecies of Sabellaria

\begin{tabular}{|c|c|c|c|c|}
\hline Species or subspecies & Distribution & Distal end of outer paleae & $\begin{array}{l}\text { Middle } \\
\text { paleae: Uni- } \\
\text { formly long } \\
\text { or alternate }\end{array}$ & $\begin{array}{c}\text { Inner } \\
\text { paleae: } \\
\text { Distal } \\
\text { end }\end{array}$ \\
\hline alcocki, ex auctore ${ }^{1}$. & $\begin{array}{l}\text { French Guiana; } \\
\text { southern California. }\end{array}$ & $\begin{array}{l}\text { Closely serrated and pro- } \\
\text { longed. }\end{array}$ & Alternate... & Entire. \\
\hline bella Grube.. & Brazil and Peru........ & Prolonged and serrate..... & Alternate... & Entire. \\
\hline bellis Hansen ........... & Brazil ............... & Slightly serrate........... & Uniform.... & Serrate. \\
\hline cementarium Moore... & Northeast Pacific...... & Penicillate. . . & Uniform.... & Entire. \\
\hline fissidens Grube.... & Chile....................... & Bifurcate & Uniform .... & Entire. \\
\hline floridensis Hartman. - & Southwest Florida. .... & $\begin{array}{l}\text { Prolonged and strongly } \\
\text { serrate. }\end{array}$ & Alternate... & Serrate. \\
\hline subspecies stephensoni, new_ & Northeast Florida...... & Shorter and serrate.......... & Alternate... & Serrate. \\
\hline gracilis Hartman .............. & Southern California..- & $\begin{array}{l}\text { Serrate, approaching peni- } \\
\text { cillate. }\end{array}$ & Uniform .... & Entire. \\
\hline nanella Chamberlin.. & Central California..... & Smooth spike................ & Uniform.... & Entire. \\
\hline pectinata moorei Monro & Balboa, Panama....... & Short serrate. & Uniform.... & Serrate. \\
\hline spinulosa Leuckart ${ }^{1}$ & Balboa, Panama....... & $\begin{array}{l}\text { Serrate, approaching peni- } \\
\text { cillate. }\end{array}$ & Uniform.... & Entire. \\
\hline vulgaris Verrill. & $\begin{array}{l}\text { New England to } \\
\text { Georgia. }\end{array}$ & Long penicillate...... & Uniform.... & Entire. \\
\hline $\begin{array}{l}\text { subspecies beaufortensis } \\
\text { Hartman. }\end{array}$ & North Carolina... & Long penicillate.. & Uniform.. & Entire. \\
\hline
\end{tabular}

${ }_{1}^{1}$ See Hartman, 1944, p. 339.

Table 1 lists the species and subspecies from the Western Hemisphere, with the distinguishing characteristics of the opercular paleae 
and distributional data indicated; more complete bibliographic references are given elsewhere (see Hartman, 1944).

SABELLARIA FLORIDENSIS STEPHENSONI, new subspecies

Figure 40

Collection.-Marineland, northern shore of eastern Florida, between tide marks; clump of tubes with many specimens.

The relative proportions of peduncle, thorax, abdomen, and cauda, for a smaller individual, are illustrated in figure 40, $a$. Opercular paleae are straw-colored; the peduncle is dorsally traversed by seven to nine slightly oblique broken bands of dark pigment, which is most intense along the middorsum and extends laterally with diminishing intensity toward the oral tentacular region. Similar though darker pigment spots occur on thoracic and abdominal neuropodia. Cauda and branchiae are paler than the other parts of the body (preserved).

Length of a larger individual is $12 \mathrm{~mm}$., excluding the cauda, which is usually turned under. Setigerous segments consist of two anterior thoracic, three parathoracic, and 20 to 24 abdominal ones. The first two are uniramous: all subsequent ones are biramous, as typical of other species of the genus. The uncinial tori of the last eight setigerous segments are slenderer and longer than the others. The cauda lacks visible annulation; when turned under it extends forward to the twelfth abdominal segment.

The opercular crown has 15 to 17 paired outer paleae, 4 or 5 shorter, and an equal number of alternating longer paired middle, and nine paired inner paleae; the total number in the outer row (30 to 34) is thus about the same as that of middle and inner rows combined. In addition, the dorsal end of the outer row has two pairs of projecting acicular spines (fig. $40, g$ ) that project freely and tend to overlap at their distal ends; their embedded bases extend back through the peduncular tissue. The outer paleal row is bound by a circlet of pale, tapering papillae that number about 24 ; they are smallest and closest together on the dorsal side.

The outer opercular paleae are long, distally serrated (fig. 40, f) with about 15 points; their flat surface is nearly smooth. Middle paleae, under low magnification, also appear smooth but under higher power are seen to be delicately spinous. The longer (fig. 40,e) and shorter (fig. 40,c) are similar to each other except in their distal ends. Inner paleae are delicately spinous along their free portions; they end in a serrated edge (fig. $40, d$ ).

Oral tentacles number about five rows on a side, and four to eight in a row; they are crowded and fill the oral area. Individually they are seen to be uniformly slender and ciliated and to have longitudinal 
rows of minute pigment spots. The palpi, to be seen by lifting the tentacles, are about as long as the latter but taper from thicker bases to slender tips.

Branchiae occur on all segments except the last few, where tori are long and slender; they are largest in the anterior half of the body and diminish thereafter so as to be absent on about the last ten segments.

Anterior thoracic segments have neuropodia only. The first has a pair of inconspicuous fascicles of very fine slender delicate setae, distally strewn with minute slender hairs. In the second segment the setae are larger and have a serrated limbate region at the free end. They resemble setae of neuropodia farther back.

Parathoracic segments are biramous. Their notopodia have single transverse rows of paleae alternating with slender acicular spines; they number about four pairs in the first, six or seven in the second, and seven or eight in the third segment. The paleae are distally broad and end in long, slender serrations (fig. 40, $b$ ).

In the abdomen, notopodial tori have uncini in single transverse series; the uncini are very minute though numerous (50 to 100 or more in a row, where best developed). Each is a pectinate plaque with five (fig. $40, h$ ) or six teeth in a single row. The cauda is smooth and cylindrical; it ends in a terminal anus.

The tubes are massed to form concreted clumps; they are sufficiently friable to be broken when dropped from a table. Individual tubes measure about $2.3 \mathrm{~mm}$. in outside diameter and $1 \mathrm{~mm}$. or less within. The individual sand grains are uniformly small, largely colorless quartz particles.

$S$. floridensis stephensoni is nearly related to the stem species from southwestern Florida. In both, the inner opercular paleae are serrated, interpeduncular spines occur at the dorsal end of the operculum, and the middle paleae alternate long and short. In the stem species, however, the outer opercular paleae are distally much longer and more strongly serrated, the peduncle is blotched rather than striped, the over-all size is somewhat greater ( 14 or $15 \mathrm{~mm}$.), and the body is more robust than in the subspecies.

Others from the Western Hemisphere with serrated inner opercular paleae are distinguished in table 1. There remain S. pectinata Fauvel (1928, p. 163) from India, with its variety intermedia Fauvel (1932, p. 210) from India, and S. cementarium Fauvel (1932, p. 210) from India (not Moore, 1906, p. 248, from the northeast Pacific). The third has outer opercular paleae with a long, smooth, slender spike and middle paleae all short. The first has greatly prolonged, strongly serrated outer paleae, and its variety, intermedia, has middle paleae 

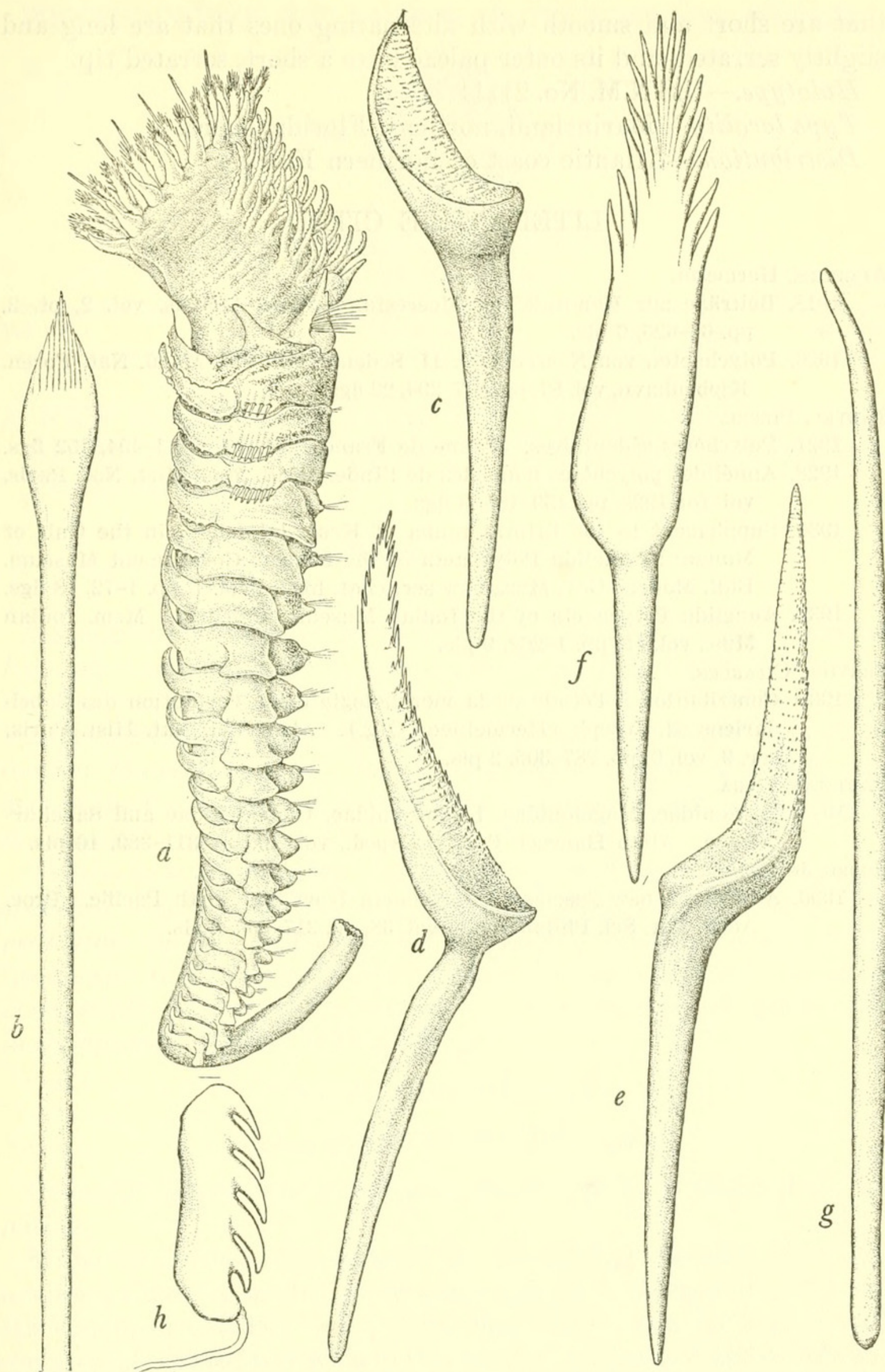

Figure 40.- Sabellaria floridensis stephensoni, new subspecies: a, Entire animal seen from the right side, $\times 16.4 ; b$, notopodial palea from second parathoracic segment, $\times 171.3$; $c$, shorter palea from middle opercular row, $\times 103$; $d$, inner opercular palea, $\times 103$; $e$, longer palea from middle opercular row, $\times 103 ; f$, outer opercular palea, $\times 85.5$; $g$, interpeduncular spine, $\times 103 ; h$, uncinus from abdominal torus, $\times 953$. 
that are short and smooth with alternating ones that are long and slightly serrated, and its outer paleae have a short, serrated tip.

Holotype.-U.S.N.M. No. 21114.

Type locality.-Marineland, northern Florida, shore.

Distribution.-Atlantic coast of northern Florida.

\section{LITERATURE CITED}

Augener, Hermann.

1918. Beiträge zur Kenntnis des Meeresfauna West-Afrikas, vol. 2, pt. 2, pp. 67-625, 6 pls.

1926. Polychaeten von Neuseeland: II, Sedentaria. Vid. Medd. Nat. Foren. Fauvel, Pierre. Kjøbenhavn, vol. 81, pp. 157-294, 22 figs.

1927. Polychètes sédentaires. Faune de France, vol. 16, pp. 1-494, 152 figs.

1928. Annélides polychètes nouvelles de l'Inde. Bull. Mus. Hist. Nat. Paris, vol. for 1928, pp. 159-165, 3 figs.

1930. Supplement to the littoral fauna of Krusadai Island in the Gulf of Manaar: Annelida Polychaeta of the Madras Government Museum.

Bull. Madras Gov. Mus., new ser. (nat. hist.), vol. 1, pp. 1-72, 18 figs.

1932. Annelida Polychaeta of the Indian Museum, Calcutta. Mem. Indian Mus., vol. 12, pp. 1-262, 9 pls.

Gravier, Charles.

1909. Contribution à l'étude de la morphologie et de l'evolution des Sabellariens St. Joseph (Hermelliens Qfg.). Ann. Sci. Nat. Hist. Paris, ser. 9, vol. 9, pp. 287-305, 2 pls.

Hartman, Olga.

1944. Paraonidae, Magelonidae, Longosomidae, Ctenodrilidae and Sabellariidae. Allan Hancock Pacific Exped., vol. 10, pp. 311-389, 16 pls.

Moore, John Percy.

1906. Additional new species of Polychaeta from the North Pacific. Proc. Acad. Nat. Sci. Philadelphia, vol. 58, pp. 217-260, 3 pls. 


\section{$2 \mathrm{BHL}$ Biodiversity Heritage Library}

Hartman, Olga. 1949. "A new marine annelid from Florida." Proceedings of the United States National Museum 99(3250), 503-508.

https://doi.org/10.5479/si.00963801.99-3250.503.

View This Item Online: https://www.biodiversitylibrary.org/item/32791

DOI: https://doi.org/10.5479/si.00963801.99-3250.503

Permalink: $\underline{\text { https://www.biodiversitylibrary.org/partpdf/20655 }}$

\section{Holding Institution}

Smithsonian Libraries

\section{Sponsored by}

Smithsonian

\section{Copyright \& Reuse}

Copyright Status: NOT_IN_COPYRIGHT

Rights: https://www.biodiversitylibrary.org/permissions/

This document was created from content at the Biodiversity Heritage Library, the world's largest open access digital library for biodiversity literature and archives. Visit BHL at https://www.biodiversitylibrary.org. 